\title{
Why They Enjoy Teaching: The Motivation of Outstanding Technology Teachers
}

\author{
Michael Wright and Rodney Custer
}

Technology education has undergone radical changes over the past decade. The content, instructional methodologies, and facilities are among the key indicators of change as is the background and motivation of people who choose to become technology teachers. Individuals interested in computers and electronic communication are seeking technology teaching positions, as contrasted with interests in woodworking and metalworking that typified the past.

The profession could benefit from information about how these changes have affected teachers' enjoyment of teaching. This information could inform the process of recruiting new teachers by better understanding the rewards and stresses associated with major programmatic change. What is it about the current teaching climate in technology education that outstanding teachers find most rewarding?

Technology education is having difficulty recruiting talented teachers. Current estimates place the number of job openings at six or more for each technology education baccalaureate graduate. Attractive salary and benefit packages accompany many of these openings. Why is it so difficult to attract and retain talented technology teachers? What is it about teaching technology education that makes outstanding teachers love their jobs?

In conjunction with an ITEA task force, a study was conducted to determine the factors associated with college students' decision to select technology teaching as a career. This research was designed to provide an information base for subsequent recruitment efforts (Wright \& Custer, 1998). Another responsibility of the Task Force was to identify the specific aspects of teaching that outstanding, nationally-recognized technology education teachers find to be particularly rewarding and most distressing. Another goal was to obtain suggestions about changes necessary to make their jobs more enjoyable.

The focus of this study is on the perceptions of outstanding technology education teachers regarding the most rewarding aspects of teaching. This information could be useful in attracting others into technology teaching.

Michael Wright is Assistant Professor at the University of Missouri-Columbia, Columbia, Missouri. Rodney Custer is Professor and Department Head at Illinois State University, Normal, Illinois. 


\section{Literature Review}

Concerns about job satisfaction spawned numerous studies during the past several decades in nearly every occupational field. There was strong interest in job satisfaction and teacher satisfaction from the late 1960s to the early 1980s. Over the past decade little attention has been paid to teacher satisfaction or its effect on students.

\section{Job Satisfaction Theories}

During the first half of the 20th century, job satisfaction was viewed as a continuum. Certain factors, if present, contributed to job satisfaction; if absent, they contributed to job dissatisfaction. In contrast, Herzberg, Mausner, and Snyderman (1959) developed the Two-Factor Theory of job satisfaction, also called the Motivation-Hygiene Theory. They concluded that there were specific conditions of employment that are job satisfiers (motivators), while other conditions act as job dissatisfiers (hygiene factors).

\section{Teacher Satisfaction and Student Learning}

Research has established a relationship between teacher satisfaction and student achievement (Adams \& Bailey, 1989; Doyle \& Forsyth, 1973; Goodman, 1980; Stanton, 1974). The findings indicate that secondary school teacher morale depends in part on whether their students were relatively high scholastic achievers. Similarly, student achievement tended to increase as a function of high teacher morale (Leslie, 1989).

Teacher morale or satisfaction may be one of the most important factors affecting student achievement, and therefore, is a critical topic to be researched. The literature on teacher satisfaction indicates that job satisfaction is the result of many interrelated factors.

\section{Job Satisfaction of Teachers}

Studies of teacher satisfaction based on Maslow's (1954) hierarchy of needs theory have supported the connection between need-fulfillment and job satisfaction (Carver \& Sergiovanni, 1971; Frances \& Lebras, 1982; Sweeney, 1981; Trusty \& Sergiovanni, 1966; Wright, 1985). These authors cited an absence of three higher-order needs (esteem, autonomy, and self-actualization) as major contributors to low teacher satisfaction.

Simmons (1970) has identified teacher satisfaction factors and has categorized them as content and context. Content factors relate to the teaching process itself (e.g., achievement in teaching, the nature of the work itself, and recognition), while context factors relate to the job situation (e.g., interpersonal relations, school policy, salary, etc.). The context serves only to reduce pain in the lower-order needs areas (e.g., physiological and safety) and cannot lead to satisfaction. The content aspects correspond to esteem and self-actualization, which are at the top of Maslow's hierarchy (Maslow, 1954). Those factors that are content-centered (i.e., intrinsic aspects of teaching) contribute most powerfully to satisfaction. 
According to a recent national survey (USDOE, 1992), approximately $32 \%$ of new teachers chose the teaching profession because they enjoy working with children. Approximately $30 \%$ found the teaching process satisfying. The same report projected that the number of teachers would need to increase from 2.8 million in 1991 to 3.3 million in 2002 to meet the demand.

Clarke and Keating (1995) discovered that interaction with students was the most satisfying aspect for teachers, while lack of administrative support was the least satisfying aspect. Perkins (1991) observed that teacher satisfaction was not significantly affected by background variables such as teacher or principal gender, years of experience, or school-type assignment. Perkins also found that teachers are most satisfied with their co-workers and least satisfied with the monetary aspects of teaching. Inadequate salary, low status of the profession, and excessive paperwork are some common sources of distress that affect job satisfaction (Kyriacou \& Sutcliffe, 1979).

Teachers' perception of locus of control is another factor influencing job satisfaction. Bein, Anderson, and Maes (1990) found a negative correlation between job satisfaction and teachers' perceptions of external control. Those with a greater sense of personal control were significantly more satisfied. This finding confirms the importance of teacher autonomy identified by Wright (1985).

Barkdoll (1991) found a differential connection between stress and job satisfaction. For example, the most satisfied teachers reported low stress and high job satisfaction, while the least satisfied teachers reported high stress and low satisfaction.

\section{Reasons for Leaving Teaching}

There is no predominant reason that teachers cite for leaving teaching. Among the reasons are salary, limited opportunities for advancement, and too much to do in too little time (Litt \& Turk, 1985). According to Ladwig (1994), another common reason for leaving is lack of support from the principal. Principals may frequently (although not deliberately) reduce or eliminate a teacher's opportunities for intrinsic rewards (Kyriacou \& Sutcliffe, 1979).

Furthermore, factors such as low salary, low status, and excessive paperwork were found to be major sources of stress among teachers. However, the intention to leave teaching was more related to their coping resources. Marlow, Inmar, and Betancourt-Smith (1996) indicated that common reasons for leaving included problems with student discipline, lack of student motivation, and lack of respect from community, parents, administrators, and students.

\section{Job Satisfaction of Technology Teachers}

Todd, Bame, Berry, Hacker, Hansen, Karsnitz, Radcliffe, Sanders, Ritz, \& White (1996) addressed the problem of the teacher shortage in technology education. Several factors and recruitment strategies were suggested, but teacher satisfaction was not addressed. Information about "job-satisfiers" is essential if the technology education profession is to better understand the recruitment and preparation of new teachers. This is especially critical given the major changes that have occurred in technology education over the past 10-15 years. 
Wright (1985), using an in-depth interview technique based on Maslow's hierarchy of needs, found a significant positive relationship between technology teachers' perceived esteem and their job satisfaction. Esteem was derived from several sources, including pride in the profession, student respect, principal recognition, program respect, community support, and professional respect. Wright's analysis, focusing on the discrepancy between desired and (perceived) actual esteem, found that satisfaction was closely related to principal recognition, satisfaction with teaching assignment, years in current assignment, and job "autonomy." Salary was not a factor related to job satisfaction. The higher-order needs for esteem were most related to satisfaction. Carvelli (1993) also found that technology education teachers place high value on and flexibility in curriculum matters.

Research by Dugger, French, Peckham, \& Starkweather (1991) report that the positive aspects of teaching technology include course content, staffing, and facilities, while weaknesses include funding, enrollment, and administrative support. The greatest problem was increased academic requirements. Other problems included lack of financial support, quality of students, and lack of administrative support.

It is clear from the review that teacher satisfaction, although a complex phenomenon, affects student achievement, and vice versa. Teacher satisfaction findings tend to support Maslow's theory of needs-fulfillment. Specifically, esteem and self-actualization on the job are factors having a significant impact on teacher satisfaction. Conversely, it would appear that "non-teaching" duties are a major source of dissatisfaction.

\section{Purpose and Research Questions}

The purpose of this study was to explore outstanding technology education teachers' attitudes about the rewards and frustrations of teaching. The study addressed the following questions:

1. What are the demographic characteristics of outstanding technology education teachers?

2. What do outstanding technology education teachers identify as the most enjoyable and rewarding aspects of teaching?

3. What do outstanding technology education teachers identify as the most frustrating aspects of teaching?

4. What kinds of assistance or change do outstanding technology education teachers identify as necessary to reduce the frustrating aspects of teaching?

5. What relationships exist between technology teacher satisfaction and demographic variables?

\section{Population and Sample}

\section{Methodology}

The population was comprised of outstanding K-12 technology education teachers in the United States. Selection as an outstanding technology education teacher required that the individual meet at least one of the following criteria: (a) 
recognition as the 1996 ITEA Outstanding Technology Teacher for their state, (b) recognition as the 1996 ITEA Program Excellence Award, or (c) recommendation by their state supervisor as an outstanding technology teacher. A total of 278 teachers were identified.

\section{Instrumentation}

An instrument was developed by the authors based on the literature review and related studies conducted in the field of technology education. A panel of experts was asked to review and critique the instrument. A modest number of suggested modifications were made and the changes were incorporated into the final version of the instrument.

The instrument consisted of two sections: (a) a demographic section and (b) a series of three open-ended questions. The demographic section requested information about age, gender, grade level taught, size of school, courses taught, years of teaching experience, extracurricular involvement of the teacher, membership in professional associations, and conference attendance patterns. The second section solicited information regarding teachers' perceptions of aspects of their jobs that they found most enjoyable as well as what suggestions they would have to improve their jobs. The open-ended format was selected in order to minimize bias which would have been introduced by a preformulated response item set. The teachers were asked to provide three responses to each of the three questions in section two of the instrument. The questions were:

1. Please list the three most important and enjoyable aspects of being a technology teacher. In short, what aspects of your job do you find to be the most enjoyable? These could include the kinds of points that you might want to make to recruit a student, friend, sibling, etc. into the Technology Education profession.

2. Please identify the three most frustrating aspects of your job, those things which might cause you to consider making a career change.

3. What kinds of assistance or change would help to reduce the frustrating aspects of your job?

\section{Procedures}

The instruments were mailed to all 278 members of the population during the Spring of 1996. A follow-up mailing was sent to all non-respondents. One hundred nineteen $(42.8 \%)$ useable instruments were returned.

Demographic data were entered into a database for subsequent analysis. Responses to the open-ended questions were compiled and entered into a database. All original wording was retained as was identification with individual demographic data. This was necessary in order to analyze satisfaction/ dissatisfaction patterns across the various demographic variables. For example, patterns of resource allocation and time demands are often quite different in large and small schools and could affect job satisfaction.

The compiled list of raw data collected in section two was individually reviewed and analyzed by the researchers. Both researchers independently compiled a summary list of items for each of the questions. The process was designed to reduce the large volume of raw data (932 responses) to a 
representative set of statements that would be (a) inclusive of all responses and (b) retain as much of the teachers' original phraseology as possible. After the independent consolidation process was completed, the two researchers reconciled differences in the lists and arrived at a final list consisting of 20 items in the "rewards" category, 31 in the "frustrations" category, and 27 in the "desired changes" category. This listing became the "key" for subsequent rating and analysis.

A team of three doctoral students ${ }^{1}$ (all with background and expertise in technology education) were then asked to independently match each of the teachers' responses with the items in the response key. Ratings were conducted independently by the three raters and the three categories of the instrument were rated separately. After all 932 responses had been matched with items on the key, the raters were asked to meet to reconcile any differences in ratings and to attempt to arrive at consensus. The initial independent ratings yielded consensus on $57 \%$ of the total response set (532 out of 932 responses). After the consensus-building session, the number of non-consensus items was reduced to $2 \%$ (19 responses). The two researchers then completed the refinement process by either (a) making a judgment about the appropriate category for the remaining non-consensus items or (b) adding a new item to the response key. The rated response sets were then analyzed for response frequencies. Additionally, responses were analyzed across the demographic data in order to detect possible response patterns.

\section{Findings and Discussion}

The population was predominantly male (89.8\%). Approximately $77 \%$ of the teachers fell within 36-50 years of age (Table 1) and had taught for 11-25 years (Table 2). Approximately one half of the teachers (50.4\%) have 10 or less years left to teach before retirement (Table 3 ). The majority of the teachers (75\%) taught in schools with enrollments of 501 or more, and were nearly evenly split between middle/junior and senior high schools (46.2\% and $45.4 \%$ respectively). It should be noted that, after the second follow-up mailing, a study of the non-respondents was not conducted and could therefore represent a source of bias.

The courses taught by the outstanding teachers and offered at their schools are shown in Table 4. Exploring technology, computer aided drafting, and communication technology were the courses most frequently taught by the teachers. General metals, welding, and photography were the courses least frequently taught.

\section{Most Enjoyable Aspects of Teaching \\ The two dominant "enjoyment" themes that emerged had to do with "excitement and stimulation of learning and working with new technologies,"}

${ }^{1}$ The authors are indebted to Patrick Foster, Randall MacPherson, and Janet Paulson for their assistance. The process was intensive and required a major investment of time and energy. 
and "the enjoyment of working with kids and making a meaningful difference in their lives" (see Table 5). The most frequently cited comments (20.5\%) were classified as "enjoyment and stimulation of learning and using new technologies - continuous change." The second and third rated categories had to do with the enjoyment of working with students and the personal satisfaction of making meaningful differences in their lives.

\section{Table 1}

Age Distribution of Teachers in Sample

\begin{tabular}{lrr}
\hline Age Range & $f$ & $\%$ \\
\hline 25 or less & 2 & 1.7 \\
$26-30$ & 6 & 5.0 \\
$31-35$ & 8 & 6.7 \\
$36-40$ & 27 & 22.7 \\
$41-45$ & 43 & 36.1 \\
$46-50$ & 22 & 18.5 \\
$51-55$ & 8 & 6.7 \\
$56-60$ & 2 & 1.7 \\
60 or more & 1 & 0.8 \\
\hline$n=119$ & &
\end{tabular}

\section{Table 2}

Years of Teaching Experience

\begin{tabular}{ccc}
\hline Years Teaching Experience & $f$ & $\%$ \\
\hline less than 5 & 15 & 12.6 \\
$6-10$ & 12 & 10.1 \\
$11-15$ & 20 & 16.8 \\
$16-20$ & 37 & 31.1 \\
$21-25$ & 22 & 18.5 \\
$26-30$ & 11 & 9.2 \\
30 or more & 2 & 1.7 \\
\hline
\end{tabular}

$\overline{n=119}$

Table 3

Years Planning to Continue Teaching

\begin{tabular}{crc}
\hline Years Yet to Teach & $f$ & $\%$ \\
\hline less than 5 & 32 & 26.9 \\
$6-10$ & 28 & 23.5 \\
$11-15$ & 29 & 24.4 \\
$16-20$ & 18 & 15.1 \\
$21-25$ & 8 & 6.7 \\
\hline $26-30$ & 4 & 3.4 \\
\hline
\end{tabular}

$n=119$ 
The fourth and fifth most frequently cited reasons were the "freedom and flexibility to be creative in developing the curriculum, selecting activities, and delivering content" (what might be considered "autonomy" on the job) and "the hands-on, action-based nature of technology education." The remainder of the responses ranged from the "authentic, relevant content of technology education" to "time off" and "job security." It should be noted that nine of the 25 positive comments were related to students in some way, and six were related to the content area of technology education (see Table 6).

\section{Frustrating Aspects of Teaching}

The most frequently cited frustration (17.6\%) was "lack of funding for equipment, supplies, and facilities." This finding would tend to dispel the notion that outstanding teachers enjoy their jobs more because they have good budgets

\section{Table 4}

Classes Taught by the Teachers and Offered by their Schools

\begin{tabular}{rlcccc}
\hline & & Taught by Teacher & \multicolumn{2}{c}{ Offered at School } \\
Course & $f$ & $\%$ & $f$ & $\%$ \\
\hline 1. & Exploring technology & 60 & 50.4 & 69 & 58.0 \\
2. & Computer aided drafting & 59 & 49.6 & 74 & 62.2 \\
3. & Communication & 53 & 44.5 & 70 & 58.8 \\
& technology & & & & \\
4. & Manufacturing technology & 48 & 40.3 & 66 & 55.5 \\
5. & Transportation technology & 43 & 36.1 & 57 & 47.9 \\
6. & Drafting; general & 42 & 35.3 & 57 & 47.9 \\
7. & Construction & 39 & 32.8 & 53 & 44.5 \\
8. & Electricity/electronics & 38 & 31.9 & 51 & 42.9 \\
9. & Robotics & 38 & 31.9 & 46 & 38.7 \\
10. & Engineering technology & 37 & 31.1 & 43 & 36.1 \\
11. & Architectural drafting & 34 & 28.6 & 51 & 42.9 \\
12. & Energy \& Power & 32 & 26.9 & 50 & 42.0 \\
13. Computer technology & 30 & 25.2 & 46 & 38.7 \\
14. & Production technology & 30 & 25.2 & 43 & 36.1 \\
15. Woodworking & 28 & 23.5 & 46 & 38.7 \\
16. & Materials/Processes & 26 & 21.8 & 35 & 29.4 \\
17. & Graphic arts & 22 & 18.5 & 35 & 29.4 \\
18. & Emerging technology & 19 & 16.0 & 23 & 19.3 \\
19. Interdisciplinary studies & 16 & 13.4 & 24 & 20.2 \\
20. & Bio-technology & 15 & 12.6 & 23 & 19.3 \\
21. & Small engines & 15 & 12.6 & 26 & 21.8 \\
22. & Photography & 14 & 11.8 & 30 & 25.2 \\
23. & Welding & 14 & 11.8 & 25 & 21.0 \\
24. & Metals; general & 10 & 8.4 & 23 & 19.3 \\
\hline
\end{tabular}

$n=119$ 


\section{Table 5}

Why They Like to Teach

\begin{tabular}{|c|c|c|c|}
\hline \multicolumn{2}{|c|}{ Positive Factors } & \multirow{2}{*}{$\frac{f}{68}$} & \multirow{2}{*}{$\frac{\%}{20.5}$} \\
\hline 1. & $\begin{array}{l}\text { Enjoyment and stimulation of learning and using } \\
\text { new technologies }\end{array}$ & & \\
\hline 2. & $\begin{array}{l}\text { The rewards of making a meaningful difference in } \\
\text { the lives of students }\end{array}$ & 49 & 14.8 \\
\hline 3. & Enjoy the kids & 34 & 10.3 \\
\hline 4. & $\begin{array}{l}\text { Freedom and flexibility to be creative in } \\
\text { developing the curriculum, selecting activities and } \\
\text { delivering content }\end{array}$ & 28 & 8.5 \\
\hline 5. & $\begin{array}{l}\text { The hands-on, action based nature of technology } \\
\text { education }\end{array}$ & 20 & 6.0 \\
\hline 6. & $\begin{array}{l}\text { Involving students in problem-solving and design } \\
\text { activities }\end{array}$ & 16 & 4.8 \\
\hline 7. & $\begin{array}{l}\text { Engaging students in authentic and relevant } \\
\text { content and activities }\end{array}$ & 15 & 4.5 \\
\hline 8. & $\begin{array}{l}\text { Opportunity to participate in professional } \\
\text { technology education associations (ITEA, TSA, } \\
\text { etc.) }\end{array}$ & 14 & 4.2 \\
\hline 9. & Student interest in technology education & 11 & 3.3 \\
\hline 10. & $\begin{array}{l}\text { Collaborating with teachers from other academic } \\
\text { areas (mathematics, science, etc.) }\end{array}$ & 9 & 2.7 \\
\hline 11. & Teaching an important subject to students & 7 & 2.1 \\
\hline 12. & Having equipment available for use & 7 & 2.1 \\
\hline 13. & $\begin{array}{l}\text { Time off for change of pace during summer and } \\
\text { school vacations }\end{array}$ & 7 & 2.1 \\
\hline 14. & Working with other technology education teachers & 5 & 1.5 \\
\hline 15. & $\begin{array}{l}\text { Community support for Technology Education } \\
\text { programs }\end{array}$ & 5 & 1.5 \\
\hline 16. & Working with computers & 4 & 1.2 \\
\hline & Teaching a subject that is growing in popularity & 4 & 1.2 \\
\hline 18. & $\begin{array}{l}\text { Motivating students to pursue technology-related } \\
\text { educational programs after high school }\end{array}$ & 4 & 1.2 \\
\hline & $\begin{array}{l}\text { Teaching a subject that increases the chances of } \\
\text { success for students with diverse learning styles }\end{array}$ & 3 & 0.9 \\
\hline 20. & $\begin{array}{l}\text { Teaching a subject connected to developing job } \\
\text { skills and exposing students to career options }\end{array}$ & 3 & 0.9 \\
\hline 21. & It's fun & 3 & 0.9 \\
\hline 22. & Contacts with business and industry & 2 & 0.6 \\
\hline 23. & Manageable class sizes & 2 & 0.6 \\
\hline 24. & Job security & 2 & 0.6 \\
\hline & Other & 35 & 10.3 \\
\hline & Total & 331 & $100 \%$ \\
\hline
\end{tabular}

$n=331$ 
and facilities. As perceived by the teachers, the lack of funding was the number one reason that could drive them from teaching. The second most frequent response (12.0\%) was the (perceived) "decline in personal characteristics and attitudes of students."

At first glance, the latter finding is surprising. The teachers' greatest satisfaction is also their greatest dissatisfaction. That is, they derive the most enjoyment from their students, while at the same time their students are one of their greater frustrations. One possible explanation is that experienced teachers had chosen to remain in teaching for the satisfaction that comes from helping students grow. However, it is also possible that certain social and environmental factors over the past decade may have eroded the overall quality of the school climate, with corresponding declines in student behavior and attitudes toward school. Thus, it may be that only a few students provide the disruption that so distracts from the teachers' overall enjoyment.

"Lack of understanding and support of technology education by administrators/counselors" was the third most frequently cited, frustrating aspect of their jobs, followed by the "long hours required to deliver a quality program." The top four frustrating aspects of teaching technology education are consistent with the literature and would likely be anticipated by most professionals in the field. What is surprising is that "low pay for teachers" was not in the top three factors (only $5 \%$ of the total responses). This finding is contrary to many national studies where poor compensation is typically among the top three factors cited. This finding is consistent with Wright's (1985) conclusion that certain intrinsic rewards (esteem and autonomy) offset (perceived) low pay, and that salary only becomes a serious issue when these intrinsic rewards are not present, or are greatly reduced.

\section{Changes Needed}

The teachers listed "better funding for Technology Education programs" as the number one change needed by a factor of more than two-to-one over the second item, "public relations campaign to interpret what technology education is, its benefits, etc." This is consistent with the frustrations cited in the section above and with the findings of Dugger et al. (1991) that funding was the most serious challenge facing technology educators. The actual magnitude of the significance of the funding factor may even be greater among the teachers included in this study. Indeed, there were seven other categories of responses that pertained to funding. These included "better compensation for teachers," "additional staff (more aides, etc.)," "additional corporate sponsorship for technology education," "assistance in seeking and obtaining funding for technology education program needs," "additional support to maintain laboratories and equipment," "support and recognition of additional extracurricular responsibilities," and "how schools are funded." Taken together, these categories comprise over one-third of all the comments related to what changes are needed.

The second major concern area dealt with educating the public and/or school officials about what technology education is, its benefits, etc., as well as 
differentiating it from instructional technology or educational technology. These comments ranged from "clarifying the purpose of technology education in the schools" to "public relations campaign to interpret what technology education is." The comments tended to focus on the lack of clarity and identification (and recognition of the) mission/purpose of technology education. The third broad area of concern was students, focusing on both student behavior and academic ability.

The balance of the suggestions (those cited more than once) are shown in Table 7. While it may not be a surprise that approximately one-third of the suggestions dealt with funding-related issues, it is surprising that there were so many other disparate suggestions (34.9\%).

\section{Factors That Were Not Frequently Cited}

It is interesting to note some of the factors that were not frequently cited. In the "rewards of teaching" category, these included "working with computers" (4 comments) and "enjoy modular technology" (1 comment) both of which some would assume to be true of our recognized "best" teachers. It is also clear that the technology teachers identified as excellent by their peers and state supervisors are not restricting their teaching to "high-tech," computer-based, or modular-based programs (Table 4).

In the "negative factors" category, the item "counselors/administrators using technology education as a dumping ground" was only noted twice. Just a decade ago, many industrial arts teachers considered this to be one of the most serious problems facing the profession (Wright, 1985). Other frustrations that were cited by only single individuals included "insufficient laboratory space," "lack of pay differentiation between good and poor teachers," and "heavy nonteaching responsibilities, meetings, and paperwork, etc." The latter was a surprise because it was specifically identified in the literature review.

Finally, in the "suggestions" category, only one comment called for "a state-mandated credit for technology education." This is in contrast to research by Dugger et al. (1991) that identified this as the most frequently cited suggestion. Other single suggestion items included "school-to-work programs," "interdisciplinary units," and "time for interdisciplinary units."

\section{Interaction Among Variables}

Research question five sought to explore relationships that might exist among the various demographic variables and technology teacher satisfaction. T-tests were run for each demographic variable on the "positive factors." Although the magnitudes varied widely, none was significantly different. This could be due, in part, to the low cell frequencies. What is particularly surprising, however, is that there was no significant difference by school size; the patterns of responses for "positive factors" and "frustrating aspects" were similar across all categories of respondents. 


\section{Table 6}

The Frustrating Aspects of Teaching

\begin{tabular}{|c|c|c|}
\hline Negative Factors & $f$ & $\%$ \\
\hline $\begin{array}{l}\text { 1. Lack of funding for equipment, supplies and } \\
\text { facilities }\end{array}$ & 63 & 19.5 \\
\hline $\begin{array}{l}\text { 2. Decline in personal characteristics and attitudes } \\
\text { of students }\end{array}$ & 43 & 13.3 \\
\hline $\begin{array}{l}\text { 3. Lack of understanding and support of } \\
\text { technology education by } \\
\text { administrators/counselors }\end{array}$ & 32 & 9.9 \\
\hline $\begin{array}{l}\text { 4. Long hours required to deliver a quality } \\
\text { program }\end{array}$ & 25 & 7.7 \\
\hline 5. Low pay for teachers & 18 & 5.6 \\
\hline 6. Excessively large class sizes & 16 & 5.0 \\
\hline 7. Lack of planning and development time & 16 & 5.0 \\
\hline $\begin{array}{l}\text { 8. Lack of status of technology education } \\
\text { profession }\end{array}$ & 13 & 4.0 \\
\hline $\begin{array}{l}\text { 9. Lack of established state/national guidelines for } \\
\text { Technology Education }\end{array}$ & 9 & 2.8 \\
\hline $\begin{array}{l}\text { 10. Difficulties associated with trying to } \\
\text { collaborate with other academic areas }\end{array}$ & 8 & 2.5 \\
\hline 11. Excessive bureaucracy and red tape & 8 & 2.5 \\
\hline $\begin{array}{l}\text { 12. Difficulties with classroom management and } \\
\text { student discipline }\end{array}$ & 7 & 2.2 \\
\hline $\begin{array}{l}\text { 13. Political problems within the community that } \\
\text { negatively impact education }\end{array}$ & 7 & 2.2 \\
\hline $\begin{array}{l}\text { 14. Colleagues who don't care about the teaching } \\
\text { profession and their students }\end{array}$ & 6 & 1.9 \\
\hline $\begin{array}{l}\text { 15. Stress and learning time associated with rapid } \\
\text { pace of technological change }\end{array}$ & 4 & 1.2 \\
\hline $\begin{array}{l}\text { 16. Shortage of like-minded colleagues or other } \\
\text { Technology Education teachers to interact with }\end{array}$ & 4 & 1.2 \\
\hline $\begin{array}{l}\text { 17. Lack of control and input into course } \\
\text { scheduling }\end{array}$ & 4 & 1.2 \\
\hline $\begin{array}{l}\text { 18. Lack of parental understanding, interest and } \\
\text { support of technology education }\end{array}$ & 3 & 0.9 \\
\hline $\begin{array}{l}\text { 19. Lack of parental involvement in children's } \\
\text { education }\end{array}$ & 3 & 0.9 \\
\hline $\begin{array}{l}\text { 20. Changes related to educational goals and } \\
\text { expectations of schools }\end{array}$ & 3 & 0.9 \\
\hline $\begin{array}{l}\text { 21. Need for lab maintenance; especially computer } \\
\text { equipment }\end{array}$ & 3 & 0.9 \\
\hline $\begin{array}{l}\text { 22. Lack of sufficient technical support to learn } \\
\text { new technologies }\end{array}$ & 2 & 0.6 \\
\hline $\begin{array}{l}\text { 23. Confusion of technology education with } \\
\text { computers and educational technology }\end{array}$ & 2 & 0.6 \\
\hline
\end{tabular}


24. Poor quality equipment and post-sales vendor

$2 \quad 0.6$ support

25. Students' lack of basic academic skills

$2 \quad 0.6$

26. Counselors/administrators using Technology

20.6

Education as a dumping ground

27. Other

Total $\quad 323 \quad 100 \%$

$n=323$

Table 7

Recommended Changes

\begin{tabular}{|c|c|c|c|}
\hline \multicolumn{2}{|c|}{ Change Factors } & \multirow{2}{*}{$\frac{f}{48}$} & \multirow{2}{*}{$\frac{\%}{17.3}$} \\
\hline 1. & $\begin{array}{l}\text { Better funding for Technology Education } \\
\text { programs }\end{array}$ & & \\
\hline 2. & $\begin{array}{l}\text { Public relations campaign to interpret what } \\
\text { technology education is, its benefits, etc. }\end{array}$ & 22 & 7.9 \\
\hline 3. & Reduction in problems with student discipline & 21 & 7.6 \\
\hline 4. & $\begin{array}{l}\text { Commitment of school district to Technology } \\
\text { Education }\end{array}$ & 18 & 6.5 \\
\hline 5. & Reduction in class sizes & 16 & 5.8 \\
\hline 6. & Better compensation for teachers & 15 & 5.4 \\
\hline 7. & $\begin{array}{l}\text { Additional staff (more faculty, teacher aides, } \\
\text { etc.) }\end{array}$ & 15 & 5.4 \\
\hline 8. & $\begin{array}{l}\text { Additional in-service and professional } \\
\text { development for technology education teachers }\end{array}$ & 15 & 5.4 \\
\hline 9. & $\begin{array}{l}\text { More control over scheduling and course } \\
\text { offerings }\end{array}$ & 13 & 4.7 \\
\hline 10. & $\begin{array}{l}\text { Reduction in paperwork, busywork, and non- } \\
\text { teaching duties }\end{array}$ & 11 & 4.0 \\
\hline 11. & $\begin{array}{l}\text { Additional corporate sponsorship for } \\
\text { Technology Education }\end{array}$ & 8 & 2.9 \\
\hline 12. & $\begin{array}{l}\text { Change public expectations of schooling } \\
\text { toward education and away from parenting }\end{array}$ & 7 & 2.5 \\
\hline 13. & $\begin{array}{l}\text { Increase communication and collaboration } \\
\text { among technology educators }\end{array}$ & 7 & 2.5 \\
\hline 14. & Students who are stronger academically & 6 & 2.2 \\
\hline 15. & $\begin{array}{l}\text { Assistance in seeking and obtaining funding for } \\
\text { Technology Education program needs }\end{array}$ & 5 & 1.8 \\
\hline 16. & $\begin{array}{l}\text { Additional support to maintain laboratories and } \\
\text { equipment }\end{array}$ & 5 & 1.8 \\
\hline 17. & $\begin{array}{l}\text { Increased parental involvement in the education } \\
\text { of their children }\end{array}$ & 5 & 1.8 \\
\hline 18 & Clarify the purpose of technology education in & 4 & \\
\hline
\end{tabular}

the schools (general education, college prep., pre-technical, etc.) 
19. Additional time and resources for curriculum development

20. Support and recognition of additional

extracurricular responsibilities (TSA

sponsorship, time spent maintaining equipment ,etc.)

21. Complete the change from Industrial Arts to Technology Education

22. Better vendor support of equipment they have sold to schools

23. Clarification of confusion between technology education and educational technology

24. Better university level support and leadership for Technology Education

25. Other Total

3

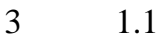

3

2

0.7

97

35.3

$n=278$

\section{Implications and Recommendations}

It is important to remember that this study dealt with "excellent" technology education teachers. Responses from the entire population of technology educators could likely have been quite different. However, it is quite clear that the teachers included in this study are committed to their students. The two primary reasons that these teachers like teaching technology is the excitement and stimulation of learning and working with new technologies, as well as the enjoyment of working with students. These teachers desire and receive a fair degree of autonomy in their daily jobs with regard to developing and implementing curriculum. The teachers in this study find the lack of funding and equipment, the decline in the personal characteristics of some students, and the lack of understanding and support of administrators and counselors to be the most frustrating aspects of their jobs.

The overwhelming majority of the suggestions offered by the outstanding teachers may be summarized in two broad categories: 1) better funding and support for technology education, and 2) educating the public (and school personnel) about technology education.

If the technology education profession is to successfully attract and retain outstanding teachers, results of this study suggest that action must be undertaken to address these concerns. Technology education professionals or their associations cannot directly address issues such as better funding for schools/teachers or issues related to student discipline. However, the profession can appropriately address the major misconceptions regarding technology education and enlist the support of business and industry in doing so. This may help alleviate the two major concerns expressed by the teachers. The following suggestions represent some practical and realistic steps for the technology education profession and its allied associations to take to address these concerns. 
1. In recruitment efforts, focus on the top three research findings: excitement of new technologies, enjoyment of working with kids, and independence and autonomy in daily routine. The results of this study, and others, clearly indicate that the rewards of teaching technology are related to both the subject and the client! This information should be used by high school teachers and counselors, university programs, and our professional associations as we attack the critical shortage of teachers in technology education. Individuals who are "peopleoriented," that is, those who enjoy working with young people, and are excited about learning and using new technologies are the best candidates for becoming successful technology teachers. We need to be bold about suggesting technology teaching as a career option to people who seem to possess these qualities.

2. The Technology for All Americans Project (ITEA, 1996) is an extremely valuable initiative to be used by the profession - not only for "standards" but also for educating school administrators, counselors, boards of education, civic groups, and technology professionals.

3. Linkages with colleges and universities (technical, design, and/or engineering). There is a great deal of activity occurring nationally with " $2+2$ " articulation programs for trade and vocational programs. A similar model could be used for establishing linkages between technology education and teacher preparation programs.

4. Local partnerships. Partnerships can be established with many different organizations/agencies including business and industry, other schools (such as elementary schools), and civic groups. These partnerships could create awareness and support for technology education.

5. Advisory committees. Advisory committees have many uses in addition to providing technical expertise. They may also be a means of involving/informing the public in/about the technology education program. Consider the role of the Technology Education Advisory Committee of the ITEA as an example.

6. Local public exhibits and presentations. If the public and administrators are to better understand the purposes, scope, and sequence of technology education, then technology educators must assume the responsibility of "educating" them. This is a process that takes many years of conscientious effort, but there are numerous examples around the country where this has been done effectively. Exhibits may be set up at schools, shopping malls, and state fairs. Presentations can be made to the school board and local civic groups.

7. Massive national public relations blitz. This is an effort that is sorely needed, but one that is probably beyond the resources of technology education professional associations. However, the associations could enlist a few large corporate sponsors. A one-page advertisement in USA Today or a 30-second spot on CNN Evening News could have awesome effects on heightening the visibility and understanding of technology education. 
8. State, regional, and national grant writing workshops and support. ITEA could provide a support structure for this initiative. Indeed, such an effort was initiated several years ago by Dr. Jane Liedtke with the support of the Technical Foundation of America. Such a program could be included at each state conference in addition to the national preconference workshops in order to assist teachers in obtaining additional resources.

We believe that these are logical, practical "next steps" for the profession. It is time to begin both large-scale and local initiatives. It is time to start carrying our message to those best able to help us, especially those in business and industry.

\section{References}

Adams, B., \& Bailey, G. D. (1989). School is for teachers: Enhancing the school environment. NASSP Bulletin, 73, 44-48.

Barkdoll, S. L. (1991). Positive affect, self-management, and stress as they relate to intrinsic and extrinsic job satisfaction (teacher job satisfaction). (Doctoral dissertation, The University of Tennessee, 1991). Dissertation Abstracts International, 53, 0668A)

Bein, J., Anderson, D. E., \& Maes, W. R. (1990). Teacher locus of control and job satisfaction. Educational Research Quarterly, 14 (3), 7-10.

Carvelli, J. J. A national study of the importance of work facets and job satisfaction levels of technology educators (Doctoral dissertation, Clemson University, 1993). Dissertation Abstracts International, 55, 0488A.

Carver, F. D., \& Sergiovanni, T. J. (1971). Complexity, adaptability, and job satisfaction in high schools: An axiomatic theory applied. Journal of Educational Administration, 9 (1), 10-31.

Clarke, R., \& Keating, W. F. (1995). A fresh look at teacher job satisfaction. (ERIC Document Reproduction Service No. ED 391 795)

Devier, D. H., and Wright, M. D. (1988). The supply and demand of Ohio industrial technology teachers: 1988-1992. Columbus, OH: Ohio Department of Education, Division of Vocational Education, Sex Equity Unit.

Doyle, G. T., \& Forsyth, R. A. (1973). The relationship between teacher and student anxiety levels. Psychology in the Schools, 10, 231-233.

Dugger, W. E., French, B.J., Peckham, S., and Starkweather, K.N. (1991). Sixth annual survey of the profession. 1989-90. Technology Teacher, 50 (4), 1014.

Frances, R., \& Lebras, C. (1982). The prediction of job satisfaction. International Review of Applied Psychology, 31, 391-410.

Goodman, V. B. (1980). Urban teacher stress: A critical literature review. Information Analyses (ERIC Document Reproduction Service No. ED 221 611) 
Herzberg, F., Mausner, B., \& Snyderman, B. (1959). The motivation to work (2nd ed.). New York: John Wiley.

International Technology Education Association. (1996). Technology for All Americans: A Rationale and Structure for the Study of Technology. Reston, VA: Author.

Kyriacou, C., \& Sutcliffe, J. (1979). Teacher stress and satisfaction. Educational Research, 21, 89-96.

Ladwig, S. A. (1994). A teacher's decision to stay or leave the teaching profession within the first five years and ethnicity, socioeconomic status of the teacher's parent(s), gender, level of educational attainment, level of educational assignment, intrinsic or extrinsic motivation, and the teacher's perception of support from the principal (Doctoral dissertation, University of La Verne). Dissertation Abstracts International, 55, A1208

Leslie, K. (1989). Administrators must consider and improve teacher satisfaction. NASSP Bulletin, 73, 19-22.

Litt, M. D., \& Turk, D. C. (1985). Sources of stress and dissatisfaction in experienced high school teachers. Journal of Educational Research, 78, 178-185.

Marlow, L., Inman, D., \& Betancourt-Smith, M. (1996). Teacher job satisfaction. (ERIC Document Reproduction Service No. ED 393 802)

Maslow, A. H. (1954). Motivation and personality. New York: Harper \& Brothers.

Perkins, C. M. (1991). A study to investigate experienced teachers' job satisfaction and the teachers' perception of their principals' leadership style (Doctoral Dissertation, The University of North Carolina at Chapel Hill). Dissertation Abstracts International, 52, A4171

Simmons, R. M. (1970). The measurement of factors of teacher satisfaction and dissatisfaction in teaching (Doctoral dissertation, University of Tennessee, 1970). Dissertation Abstracts International, 31, 3239A.

Stanton, H. E. (1974). The relationship between teachers' anxiety level and the test anxiety level of their students. Psychology in the Schools, 11, 360-363.

Sweeney, J. (1981). Teacher dissatisfaction on the rise: Higher-level needs unfulfilled. Education, 102, 203-207.

Todd, R., Bame, A., Berry, C., Hacker, M., Hanson, R., Karsnitz, J., Radcliffe, D., Sanders, M., Ritz, J., \& White, R. (1996, November/December). Teacher shortage and recruitment: A problem and an opportunity. Ties Magazine, 14-16.

Trusty, F. M., \& Sergiovanni, T. J. (1966). Perceived need deficiencies of teachers and administrators: A proposal for restructuring teacher roles. Educational Administration Quarterly, 2, 168-180.

U. S. Dept. of Education. 1992. America's teachers: profile of a profession. Document \# 065-000-00567-1, Government Printing Office, Pittsburgh, PA.

Wright, M. D. (1985). Relationships among esteem, autonomy, job satisfaction and the intention to quit teaching of downstate Illinois industrial education teachers. (Doctoral dissertation, University of Illinois, Urbana-Champaign, 1985). Dissertation Abstracts International, 46, 3273A. 
Wright, M. D. (1992, November). Results of a nationwide survey to evaluate factors associated with students' decision to become technology education teachers and the perceived effectiveness of various recruitment practices and activities. Paper presented at the 79th Annual Conference of the Mississippi Valley Industrial Teacher Education Conference, Chicago, IL.

Wright, M. D., \& Custer, R. C. (in process). Factors associated with students' selection of technology teacher education as a major. 